\title{
Trajetórias de vidas e lutas pela demarcação das terras indígenas. Uma entrevista com Cretã Kaingang (PR) e Davi Karaí Popygua (SP)
}

\section{Entrevistados}

\section{Romancil Gentil Cretã}

Coordenador politico da ARPIN-Sul ( Articulação dos Povos Indígenas da Região Sul), Fundador do Acampamento Indígena Revolucionário (AIR), Cofundador e presidente da associação denominada ORCCIP CURIM - Organização de Resgate Crítico da Cultura Indígena Curitiba e Região Metropolitana. Filho de Ângelo de Souza Cretã, líder Kaingang assassinado numa tentativa de retomada de terras indígenas nos anos 1980. Atual liderança da Terra Indígena de Mangueirinha, localizada no sudoeste do Paraná entre os rios Iguaçu (Covó) e Lageado Grande.

\section{Davi Karaí Popygua}

Atua na Comissão Yvyupa, é professor guarani na escola localizada na aldeia Tekoá Pyaú, Terra Indígena Guarani Jaraguá, conhecida como Pico do Jaraguá em São Paulo. Atual liderança indígena de Jaraguá

Entrevista concedida em: 09/04/2018
Entrevistadoras

\section{Carmem Susana Tornquist}

Doutora em Antropologia Social pela Universidade Federal de

Santa Catarina - UFSC.

Professora da Univ. do Estado de

Santa Catarina - UDESC. Brasil

carmentornquist@hotmail.com

\section{Raquel Mombelli}

Doutora em Antropologia Social pela Universidade Federal de Santa Catarina - UFSC.

Professora da Universidade

Federal de Santa Catarina - UFSC. Brasil

mombelliraquel@gmail.com

Transcrição

Ana Paula Maciel Soukef Mendes Doutora em Ciências Humanas pela Universidade Federal de

Santa Catarina - UFSC. Brasil

anasoukef@gmail.com

\section{Para citar esta entrevista:}

CRETÃ, Romancil Gentil; POPYGUA, Davi Karaí. Trajetórias de vidas e lutas pela demarcação das terras indígenas. Uma entrevista com Cretã Kaingang (PR) e Davi Karai Popygua (SP) [Entrevista concedida em og de abril de 2018]. Revista PerCursos. Florianópolis, v. 19, n.39, p. 206 - 228, jan./abr. 2018. Entrevistadores: Carmem Susana Tornquist e Raquel Mombelli.

DOI: $10.5965 / 1984724619392018206$

רttp://dx.doi.org/10.5965/1984724619392018206 


\section{Falas de Cretã Kaingang (Romancil Gentil Cretã - PR) e de Davi Karaí Popygua} $(\mathrm{SP})$

Na tarde do dia 9 de abril de 2018 aconteceu a abertura da $13^{\text {a }}$ Semana Cultural Indígena, no Morro dos Cavalos, litoral catarinense. O evento, já tradicional no calendário da comunidade Mbyá Guarani, revestiu-se de especial importância no ano de 2018, em razão da intensificação dos ataques e retrocessos políticos envolvendo os direitos dos povos indígenas, que vêm tomando conta do cenário brasileiro nos últimos anos. Processo dialético que vem gerando fortes resistências por parte dos povos indígenas, a partir de movimentos organizados nos quais despontam lideranças jovens e mulheres; e em uma instigante e criativa articulação entre saberes das novas gerações de indígenas e conhecimentos dos mais antigos, figuras de grande importância para essas tradições.

A abertura foi marcada pelo debate político acerca da atual situação desses povos no Brasil, na qual tem se destacado o aumento dos conflitos relacionados aos direitos territoriais. Desta atividade participaram várias lideranças locais e nacionais do movimento indígena. Em meio às intensas atividades deste dia, conseguimos realizar uma conversa conjunta com Cretã Kaingang, da Terra Indígena (TI) ${ }^{1}$ Mangueirinha, e coordenador da Articulação dos povos indígenas do Sul (ARPIN-Sul), e Davi Karaí Popygua, da Comissão Yvyrupa e liderança da Terra Indígena do Jaraguá. As falas que se seguem correspondem a essa conversa, realizada com Carmen Susana Tornquist e Raquel Mombelli, em uma sala de aula da Escola Itaty e acrescida das falas públicas (depoimentos), realizadas a seguir, durante a mesa redonda que se intitulou "Articulação dos três poderes contra os direitos dos povos indígenas e a luta pelo território Guarani". Nesta ocasião, pronunciarem-se, ainda, a ex-cacique da TI Morro dos Cavalos, Kerexu Yxypyry (Eunice Antunes), a cacique da Aldeia Yakã Porã, Elizete Antunes, além de outras lideranças da região, Davi Guarani e Marciano Rodrigues. A abertura da mesa contou também com a presença das crianças e jovens guarani do Coral Mborai Vya, da Tekoa (Terra Indígena) Vya, que se situa no município de Major Gercino, em Santa Catarina.

\footnotetext{
${ }^{1}$ Para fins deste texto, utilizaremos como sinônimos de território tradicional as expressões Terra Indígena ou tekoá (em guarani).
} 
Assim, ao que os leitores e leitoras terão acesso, a seguir, são as falas dessas lideranças em um formato misto - entrevista semi-diretiva seguida do depoimento público - face à constatação de que as perguntas referentes às lutas atuais, previstas pelas entrevistadoras, foram alvo das falas proferidas pelos entrevistados durante a mesa redonda. Essas falas foram transcritas por Ana Paula Soukef Mendes.

Davi Karaí Popygua faz parte da Comissão Yvyrupa, que reúne representantes das terras e aldeias indígenas Guarani de todo o Brasil, e é liderança da Terra Indígena Jaraguá, situada na cidade de São Paulo. Este território ocupa uma área situada na cidade de São Paulo, conhecida como Pico do Jaraguá. Em meados de 2017, o governo do estado de São Paulo obteve o apoio do Ministério da Justiça na busca da redução drástica da área, através da Portaria 683/2017, gerando fortes protestos e a ocupação do Pico do Jaraguá, local estratégico para as empresas de telecomunicação. O Jaraguá é expressivo de outros casos envolvendo os Guarani que vivem no Brasil, pois envolve conflitos entre governos estaduais, a chamada "sobreposição" de áreas protegidas e a presença de indígenas em áreas urbanas.

Cretã Kaingang é filho de Ângelo Cretã, primeiro vereador indígena do Brasil, marcado por uma intensa atuação na luta pelos direitos indígenas. Ângelo Cretã faleceu em janeiro de 1980, em um enigmático acidente de carro, em plena luta pela retomada de territórios, no Paraná. A Comissão Nacional da Verdade incluiu este caso no seu relatório, em razão dos indícios de se tratar de um assassinato e por nunca ter sido apurado com seriedade. Cretã Kaingang vive na Terra Indígena Mangueirinha, no sul do Paraná, na qual convivem comunidades Guarani e Kaingang, cujo processo de reconhecimento até hoje está inconcluso, expressando boa parte dos conflitos fundiários. Cretã atualmente faz parte da ARPIN - SUL, a qual veio representar no dia 9 de abril, no Morro dos Cavalos.

\section{Davi Popygua: terra sagrada e trajetórias de lutas pela demarcação}

\section{Depoimento}

Nhandekaruju. Boa Tarde! 
Bom, primeiro eu queria muito dizer a importância que tem esse momento para gente, estar aqui, somando junto com a comunidade do Morro dos Cavalos e dizer que o Jaraguá tem passado por uma luta grande, de onde eu venho, lá em São Paulo, porque algo inédito aconteceu, que a gente não esperava, que foi a anulação da nossa portaria ${ }^{2}$ pelo Executivo. O Executivo é responsável por reconhecer o território indígena, mas aí enfrentamos uma situação em que o processo de reconhecimento vira o contrário - a desdemarcação de terra. Então, com a conjuntura desse governo golpista, a gente tem uma realidade de vários ataques, um bombardeio ao nosso direito, dos povos indígenas. Essa medida, que foi feita pelo Ministério da Justiça, através de uma portaria 683 , foi a anulação da portaria declaratória da Terra Indígena do Jaraguá. A Terra Indígena do Jaraguá é uma terra Guarani, que compõe todo o nosso território. É muito importante a gente deixar claro, para todas as pessoas e para esse estado brasileiro, que o território Guarani é um só, e, então, “mexeu com um Guarani está mexendo com todos, mexeu com um indígena está mexendo com todos”. Nós estamos aqui nessa articulação, junto com o Morro dos Cavalos, para dizer que esse território é Guarani e que vai resistir a esse processo de ataque aos direitos. Nós tivemos uma luta muito grande para conseguir o reconhecimento do nosso território, dentro daquilo que o juruá impôs como processo demarcatório. Primeiro que nós não entendemos a terra como algo a ser demarcado, porque a terra não nos pertence. Ela é algo muito mais sagrado do que a pequena existência do ser humano, porque a terra é a nossa mãe e é a mãe de todos os seres vivos. Essa luta indígena não é só nossa, a luta pelo território não é só nossa, é uma luta de todos os seres humanos. A gente precisa, cada vez mais, traduzir a luta indígena para o que realmente é o sentido da vida e da terra, e nós, povos indígenas, temos esse conhecimento e é através de iniciativas como essa, hoje que tá acontecendo, que a gente vem, chama as pessoas para conhecer um pouco da nossa realidade.

A Terra Indígena do Jaraguá foi homologada em 1987, ela foi homologada antes da Constituição Federal de 88, e foi homologada com 1,7 hectares, sendo ali reconhecida como a menor terra indígena do país. De lá pra cá, a gente não aceitou, de forma alguma,

\footnotetext{
${ }^{2}$ Referência à Portaria Declaratória $n^{\circ}$ 581, de 2015, do MJ, que reconheceu a área como território tradicionalmente ocupado.
} 
essa homologação com 1,7 hectares, porque isso foi um processo de imposição do Estado. Ainda hoje o Estado entende que nós indígenas devemos ser integrados, não devemos ter o direito à terra, não podemos manter a nossa cultura, não podemos manter a nossa forma de vida tradicional. Mas essa é a resistência indígena, a resistência pelo direito à nossa cultura, à nossa vida, ao nosso modo de ser. Então, a partir da Constituição de 88 , começa a se rever esse processo de reconhecimento através da lei, mas na prática o Estado brasileiro ainda é dominado por pessoas que sempre agiram na contramão da vida, por pessoas que têm uma consciência, um pensamento, um coração muito pequeno diante do que realmente representa a terra pra todos nós. Então nós fazemos uma luta pelo reconhecimento do nosso território, mas sempre pensando que o princípio de tudo não é de que nós somos donos da terra, mas que nós fazemos parte dela e que é importante que ela exista, para que mantenha a nossa vida e a vida de todos vocês. Nós, Guarani, somos o povo da Mata Atlântica, nós estamos vendo, ano a ano, os projetos de empreendimento, projeto de progresso, modelo de progresso desse país passando por cima não só das nossas vidas, mas de todo o bioma que compõe o território Guarani. A cada ano são milhares de hectares que são desmatados em nome do progresso. Então, isso para nós é muito forte quando se fala da destruição do nosso território, porque sem a terra não existe vida para nós indígenas. A terra, ela é sagrada. A Mata Atlântica é um lugar sagrado, ela é um templo sagrado, e nós Guarani estamos dizendo, desde a invasão do não indígena, que essa terra precisa ser respeitada, que é uma forma de se viver nessa terra. Mas o juruá, ainda hoje, quer crescer esse pensamento de progresso, de destruição, de exploração dos recursos naturais, como se isso não tivesse fim. E o que eu fico pensando, esses dias eu estava conversando com um xeramõi, eu estava perguntando para ele como é que vai ficar? Porque o juruá está destruindo completamente a resistência da terra para manter a nossa vida, só que nós vamos pagar por esse processo de progresso, esse modelo de progresso, com a nossa existência. O que ele me disse é que um dia Nhanderu ${ }^{3}$ e a terra vão cobrar da humanidade o que está sendo feito. Vem muito rápido esse processo de extermínio de todos, de tirar, de varrer da terra essa raça do juruá que não respeita a terra, essa raça do juruá que não consegue pensar, como nós

\footnotetext{
${ }^{3}$ Grosso modo, seria correspondente a "deus", em português.
} 
estamos pensando, de proteger a terra como mãe. A luta nossa, indígena, é a mãe de todas as lutas porque é a primeira luta de resistência nesse país, desde essa invasão. Ainda hoje nós somos vistos como minoria, ainda hoje querem categorizar a gente como povo coitado, mas nós não somos este tipo de povo, nós somos o povo originário, nós temos um conhecimento sobre esse território, nós temos o conhecimento sobre a nossa história. Esse território é herança dos nossos avós, e aqui nós estamos dispostos a dar a nossa vida. Nós temos sonhos muito grandes, porque o juruá, esses juruá que vivem hoje destruindo tudo, eles não sonham mais. Eles perderam a capacidade de sonhar, eles só conseguem sonhar com eles mesmos. Os nossos sonhos vão muito além, e são eles que fazem com que a gente acredite ainda que há a possibilidade de coexistir a vida da humanidade com a terra, porque nós temos o conhecimento sagrado de como conviver com a terra. Então, nesse pensamento, se forma a resistência do povo indígena, lutando pelo seu modo próprio de ser. Nós não queremos deixar de ter o nosso território, a nossa forma própria de vida. O Estado brasileiro, a cada ano, se articula de uma nova forma, ele cria uma nova forma de tentar acabar com a existência indígena. Então são centenas de projetos de lei, que tramitam no Congresso, que visam acabar com o direito constitucional, com os direitos conquistados pelos povos indígenas. Nessa articulação entre os três poderes, para mim, o grande carro-chefe dessa aliança é o poder econômico, que é quem financia essa bancada ruralista, essas bancadas que agem na contramão do direito dos povos, do direito à vida dos seres humanos e dos seres vivos. Então é o momento da grande união entre os movimentos, entre os povos. A consciência precisa partir de cada pessoa, para que não só nós, povos indígenas, continuemos fazendo a frente dessa luta pela resistência, pela terra, mas os movimentos possam também se articular, conhecer, e se preparar para fazer a defesa da nossa mãe, que é a mãe de todos nós, que é a terra. Então, no Executivo, esse ano de 2016, foi quando houve essa mudança que a gente já tinha anunciado que seria o verdadeiro massacre promovido por esse governo golpista. E isso se colocou na prática realmente, porque assim que esse governo entra, ele começa a criar uma série de medidas anti-indígenas, entre elas, a cada ano, a cada dia, a FUNAI vai se desfazendo, vai se desconfigurando, vai cortando recurso, vai-se impedindo que ela cumpra com a sua função administrativa de reconhecimento dos 
territórios indígenas. Também essa ação de anulação da portaria declaratória foi algo muito grave, em que eles pensaram, "vamos mexer com uma terra indígena de 1,7 hectare que não vai apresentar muita resistência", mas o que nós temos, como eu falei, são os nossos sonhos. É o sonho que dá força pra gente continuar na nossa luta. Então o juruá não esperava. Esse ministro da Justiça, Torquato Jardim, ele não esperava uma resistência do povo Guarani. Mas nós fizemos a nossa reza, fomos buscar de Nhanderu as respostas do que a gente podia fazer para reverter essa anulação da portaria declaratória, e foi com muita fé que a nossa comunidade fez uma resistência grande. Conseguimos fazer as nossas mobilizações, conseguimos envolver a sociedade, e aí que entra a importância da sociedade se aliar com os povos indígenas para o fortalecimento dessa luta, para que possa propagar o que a gente passa na nossa comunidade para todo o mundo, a realidade, a situação da reintegração de posse, a situação da violência, a criminalização das lideranças, que é algo muito grave que tem acontecido cada vez mais também. O Estado articulado, atendendo o interesse do poder econômico, ele começa a agir em todas as frentes, criminalizando as lideranças indígenas. Nós tivemos, recentemente, o caso do nosso parente do Acre, o Benki Ashaninka ${ }^{4}$, que é uma situação muito revoltante. Nosso parente sofrendo ameaças, foi entrar com um pedido de segurança, ele foi pedir proteção para o Estado e o Estado não acata esse pedido e entra com uma ação contra ele, de calúnia e difamação, dizendo que ele estava acusando pessoas que estavam querendo ameaçar ele. Ele [o Estado] ficou do lado do branco, criminalizando a nossa liderança, criminalizando uma grande liderança, que luta pelos Direitos Humanos, que luta pela terra com tanta coragem. O Brasil é o país em que mais morrem ambientalistas no mundo; os defensores dos Direitos Humanos estão morrendo no Brasil, e muitas pessoas veem essa situação acontecendo e não fazem nada pra contribuir. Então é esse o nosso pedido, para que a sociedade, para que os movimentos tenham uma compreensão da importância que é, e a urgência que é das articulações, para que a gente tenha mais força para enfrentar esse estado. Então essa situação da criminalização realmente é grave. Todas as vezes que nós vamos cobrar do estado para que ele respeite o nosso direito nós sofremos a criminalização, nós sofremos a ação

\footnotetext{
4 Referência ao caso envolvendo Benki Piyãnco, do povo Ashaninka, que após registrar denúncia de perseguição, acaba sendo acusado de promover calúnias indevidas, pelo Ministério Público do Acre.
} 
violenta da polícia, e aí como é que fica para nós, povos indígenas, continuar a nossa luta? É essa força que a gente tem, que o juruá não entendeu, que enquanto tiver um indígena vivo nessa terra, vai existir esperança. Nossos xeramõis e os pajés de todos os povos, eu acredito que tenham o mesmo pensamento. Todos os anciões indígenas, eles dizem que enquanto existirem os pajés rezando para que exista a vida, ela vai existir. Mas quando o último indígena, que tem a consciência do que é a terra, deixar de existir, aí acabou a esperança de vez. Então este tipo de profecia é algo muito sério, porque vem desde antes da invasão do branco, do juruá. No nosso território a gente já tinha a consciência que se a gente não respeitasse a terra, a gente não ia existir. Então é assim que o nosso pensamento funciona. Essa luta é nossa, indígena, mas é de todos. Eu agradeço muito vocês que estão aqui, no Morro dos Cavalos, contribuindo com esse lançamento da campanha. Vamos fortalecer essas articulações cada vez mais. Tem muito mais coisas para eu compartilhar com vocês, mas a nossa luta segue. A gente tem formas de se aproximar. Eu acho que é importante as redes sociais, por exemplo, como um instrumento nosso de denúncia, os coletivos que estão aqui, utilizarem as redes sociais para divulgar a luta do povo indígena, acompanhar as páginas que existem na internet. Existe a página da APIB (Articulação dos Povos Indígenas do Brasil), a página da Comissão Guarani Yvy Rupá, ARPIN Sul, todas as organizações indígenas estão acompanhando o que está acontecendo de norte a sul, que na verdade o que está em curso hoje é uma tentativa de um verdadeiro massacre dos povos indígenas de todos os lados. E somos nós que estamos aqui, representando essa história, essa luta, que estamos aí, cada dia mais sonhando alto com um futuro melhor. Então muito obrigado pela atenção de vocês e aguyjevete a todo o povo de luta.

\section{Entrevista}

Entrevistadoras: Gostaríamos que você falasse, inicialmente, sobre sua trajetória política Como é que a luta política acontece na sua vida?

Davi: Sou Davi Karaí Popygua, sou Guarani da Terra Indígena do Jaraguá, tenho 30 anos, sou uma liderança da comunidade. Nós, lideranças Guarani, para nos constituirmos como 
liderança, a gente passa por um processo de amadurecimento, é um reconhecimento também dentro das nossas comunidades pelos núcleos que compõem as famílias da aldeia. Então é muito mais uma vocação do que um processo de escolha. Isso é algo que desperta, dentro, o espírito de cada um, e para mim foi muito cedo, que eu comecei acompanhando meus avós, acompanhando as lideranças, nas discussões da comunidade pelo direito, na luta pelo direito. Então fui acompanhando essas lutas e tenho uma referência muito grande na minha vida que é a minha avó, Kerexu. Eu cresci assim, vendo as pessoas indo na comunidade, conversar, o que precisava para comunidade, o que tinha de demanda, qual era a necessidade maior do nosso povo. E a necessidade maior sempre foi o reconhecimento do nosso território, a garantia do território para que a gente pudesse viver da nossa cultura, para que a gente pudesse viver dentro do nosso território sem essa invasão, sem domínio, sem exploração do nosso território. Nosso conhecimento guarani pensa o território como uma única terra, a gente não imagina a terra como vários países, estados, como é tão dividido hoje. E isso já é um processo histórico da composição do território Guarani como Yvy Rupá, que é uma terra só, não onde tem os Guarani compõem esse território.

\section{Entrevistadoras: Como é esta composição do território?}

Davi: A gente parte do princípio que a terra é uma só e aí essa consciência de que todo o território Guarani é parte de algo muito sagrado, que foi colocado para que a gente pudesse viver e respeitar a terra como uma mãe. Eu via essa parte que minha vó falava da demarcação, do reconhecimento da terra, mas quando eu era criança, eu via ainda que esse processo de demarcação, ele ainda estava muito no início da compreensão dos próprios Guarani, porque é um processo que foi se modificando, muita luta do movimento em décadas passadas para que chegasse até a Constituição de 88. Então, foi um marco o reconhecimento do direito indígena ao território quando o Estado reconheceu o artigo 231 da Constituição, que reconhece o território e reconhece também essa dívida histórica do Brasil, dos estados em geral onde tem população indígena aqui no Brasil, que roubou nosso território. Aí eu via a minha avó como uma mulher indígena e achava interessante porque ela era a única cacique no meio dos caciques Guarani. Não 
tinha ainda mulher Guarani cacique, não tinha mulher indígena na luta assim, mais com as lideranças, então, eu achava interessante. Depois que eu fui compreender quem ela era: ela foi reconhecida como a primeira mulher indígena a ser uma cacique de que se tem registro na história.

\section{Entrevistadoras: Como é o nome dela?}

Davi: Kerexu. Foi aí que eu percebi a importância da luta que ela fazia. E eu via a angústia dela muitas vezes de não saber falar bem português. Ela não conseguia traduzir em português a angústia que a comunidade enfrentava, ela tentava falar, mas não conseguia se expressar. Quando era (para falar) nas assembleias Guarani, ela desenvolvia muito bem, falando a nossa língua, mas quando ia falar para o não indígena, não conseguia. Então aquilo começou a me despertar avontade de ajudar a traduzir o sentimento dela, como uma líder já antiga do nosso povo, para o português. Foi quando ela começou a confiar em mim também para que eu fizesse a fala por ela, que eu traduzisse mais esse sentimento. Porque a fala, para a gente, está muito mais ligada ao espírito do que propriamente às palavras ditas. É algo que vem de dentro do coração, para nós, Guarani. Foi aí que eu fui participando, quando eu tinha 15 anos, 14 anos, ela me chamava para ir para as reuniões e falar. Não era normal também um jovem ser uma liderança, falar como uma liderança, porque era muito difícil. Uma liderança Guarani se constitui com mais de 30, 40 anos pra ser reconhecida. É um processo de amadurecimento espiritual e amadurecimento físico também, psicológico, tudo. Então, para mim foi assim, essa responsabilidade de novo, de já falar pela comunidade, eu fui entendendo mais e me apropriando dessa questão do direito indígena. Foi quando eu comecei a ler mais, estudar mais, entender esta questão do documento, do papel. Porque para nós, indígenas, a transmissão do saber de forma oral é muito forte. As histórias são milenares, da cultura, do nosso conhecimento. Mas aí vem o juruá com essa papelada toda dizendo: olha, todo esse papel diz que vocês não têm direito. E que papel é esse? Eu via muitas histórias dos mais velhos, em que eles falavam da década de 50, década de 60 , em que eles ainda não

\footnotetext{
${ }^{5}$ Termo utilizado entre os Guarani Mbyá para se referir aos não indígenas.
} 
tinham muito essa compreensão de qual era esse processo burocrático que o juruá impôs pra o reconhecimento de um território, porque o Guarani tem uma consciência de terra muito livre, um território livre, de grandes caminhadas, de um caminho espiritual que é transitório. A gente costuma falar que é como se fosse um território em espiral, assim, que é um círculo, dentro da América do Sul. Os Guarani foram a várias regiões da América do Sul, desde as Cordilheiras dos Andes até a ponta do continente, o Uruguai; a região sudeste do Brasil; se fala do Caminho de Peabiru que ia até o Peru, nos Incas. Então, é um conhecimento do território da América do Sul muito amplo. A gente cresce ouvindo essas histórias dos nossos xeramõi ${ }^{6}$. Mas vem a questão dessa demarcação e de compreender o que é essa demarcação. Foi aí que houve muito esforço também dos mais antigos para que a juventude se apropriasse do conhecimento, da linguagem, da escrita, da leitura, para que não houvesse mais tanta injustiça como a que se cometia com esses documentos. Foram muitas e muitas as vezes em que minha avó me chamava para ler um ofício, um documento, alguma coisa que chegava na comunidade, pois eram poucos os Guarani que sabiam ler e escrever. Ela não confiava no branco, pois foi nessa "confiança" que muito do nosso território foi perdido, foi nessa confiança que a gente foi traído por parte do não indígena, de querer impor pra gente esse sistema burocrático de direito, dentro de um papel, de uma assinatura. Então, eles começaram a entregar as terras indígenas. Tem muitos documentos que comprovam que o Serviço de Proteção ao Índio removia comunidades, fazia documentos para dizer que não tinha mais indígena ali, para dar para o fazendeiro, para tudo, para exploração. Eu venho desta história... Sou um jovem ainda, mas eu passei por esse processo de transição, de ouvir dos mais velhos que era importante nós, como lideranças jovens, equilibrarmos o nosso conhecimento, ter a nossa cultura fortalecida dentro da gente, viver a nossa cultura, mas também conhecer o mundo do não indígena, as formas de domínio que eles exercem, que querem exercer sobre a gente.

\footnotetext{
${ }^{6}$ Anciãos e conselheiros do povo Guarani.
} 
Entrevistadoras: Gostaríamos que você contasse um pouco sobre o processo que levou à inclusão dos artigos 231 e 232 na Constituição brasileira, que, como você comentou, são vistos como grandes avanços para os povos indígenas...

Davi: Esse processo também veio com a Constituição de 88 , que foi uma luta muito grande das lideranças, que os Guarani também lutaram. Eu tenho um tio que conta as histórias de quando eles iam pra Brasília, o xeramõi Altino, que é primo da minha avó, que passou pelo processo da Constituinte, dessa conquista do povo indígena. Eles queriam muito que houvesse um processo de formação para esses jovens, essas crianças, para que elas pudessem ter mais ferramentas para resistir. Foi aí que eu comecei a estudar, com a compreensão de que eu tinha que aprender aquilo, tinha que aprender a me expressar em português, tinha que aprender a interpretar a linguagem do não indígena, como uma forma de defesa e de resistência também. E hoje já é uma realidade para nós. A juventude tem cada vez mais se fortalecido e se apropriado dessas ferramentas de resistência e contribuído muito com a nossa luta. A gente já não tem mais aquela forma de ser dominado, tutelado. A compreensão que veio é de que realmente toda a luta indígena, essa resistência desses avós, gerou o direito que nós temos hoje da forma tanto do branco, mas a gente sempre teve nossa consciência, de que somos um povo, de que temos uma originalidade dentro desse território, que somos os povos originários. Então, aliamos esses conhecimentos, claro que sempre consultando os nossos xamãs, que são nossos pajés, para que a gente tenha força para fazer essa luta. Desde então, eu tenho me dedicado para o movimento indígena, para luta indígena, na luta e na resistência pelo direito do nosso território. E isso é uma luta histórica nossa, porque desde que houve a invasão do não indígena já começou esse processo de domínio, de massacres, de violência contra nós. Porque as histórias que a gente ouve dos nossos xamãs são de muita violência, muita guerra, muito massacre, são muito duras e nos livros do não indígena, não estão registradas. A gente tem uma necessidade muito grande de ouvir essas histórias e reproduzi-las para as futuras gerações. Esse é o processo contínuo de formação de novas lideranças. Foi dessa formação que eu hoje me constituí, assim, pela comunidade, como um representante dessa luta. 
Entrevistadoras: Você pode falar um pouco a respeito da criação do Parque Estadual do Pico do Jaraguá sobre a terra indígena?

Davi: Houve muitas formas do Estado tentar acabar com o território indígena, desde o genocídio, as guerras, os conflitos. E há essa estratégia da criação de parques, também, ou, como se diz, reservas florestais, que eles colocam como sendo áreas de proteção ambiental, mas que na verdade, fica muito claro quando há um interesse dos poderes econômicos e políticos que combinam. Eles colocam como barganha de troca as reservas florestais, e aí a gente falar que o território Guarani é a Mata Atlântica, então a Mata Atlântica é um bioma que está muito ameaçado, é o bioma mais ameaçado do mundo. E o que os nossos xeramõis xamãs contam é que o bioma da Mata Atlântica era tão grande quanto a Amazônia, mas o processo de invasão e de destruição do território foi tão forte que hoje restam poucos remanescentes da Mata Atlântica, comparado com o que era antes. Então, para nós é importante a defesa do território para que não haja realmente essa destruição do pouco território nativo que ainda temos. Muito dos territórios já estão muito degradados pela soja, pelas monoculturas, pelo eucalipto, mas hoje, nos locais onde há Mata Atlântica, ainda é onde está o povo Guarani. Éuma luta de resistência não só pela nossa vida, mas por esse bioma que é tão importante, que chamamos de ka'agüy porque na cultura Guarani a consciência de território, a origem da vida Guarani nasce dentro de um lugar que os xeramõi chamam de káagüy ete, que é o centro da terra, o centro da grande floresta. A Mata Atlântica abrangia praticamente todo o Paraguai, a Argentina, o litoral do Brasil, toda a parte litorânea. Hoje ela pega só algumas partes do Paraguai, da Argentina e poucas do Brasil. Apesar de envolver 15 estados, restam menos de $8 \%$ da Mata Atlântica. Então, a nossa vida é dentro desse bioma, nosso conhecimento e nossa luta não é só pela nossa vida, mas é pela proteção desse lugar que é como um templo sagrado. A natureza é um templo sagrado; não há essa compreensão por parte do não-indígena, mas é aí que tentamos conscientizar através de ações como essa que está acontecendo hoje aqui, da semana cultural e dos outros eventos que fazemos; é a forma que a gente tenta de conscientizar a sociedade. Muitas vezes a ação do governo é muito violenta e muito rápida, e a gente tem que dar uma resposta como defesa do nosso 
direito, e aí, muitas vezes, temos que partir para uma mobilização, para uma manifestação, porque a gente tenta resolver as coisas no diálogo, porque foi assim que aprendemos como Guarani, só que o governo age com reintegração de posse, querendo anular uma demarcação. Então, a gente tem que dar essa resposta e é aí que a nossa comunidade está pronta para essas lutas quando for necessário, então é assim que a gente se articula.

\section{Cretã Kaingang (Romancil Gentil Cretã) - Protagonismo das chefias na retomada territorial e cultural}

\section{Depoimento}

Boa tarde a todos e a todas. Quero agradecer ao cacique e agradecer a essa comunidade, e um agradecimento especial a Kerexu, por ter me convidado pra fazer parte dessa mesa. Eu vim aqui somar, buscar esta unidade entre nós, Kaingang, Guarani, Xokleng, Xetá, Charrua... que são os cinco povos aqui da nossa região. Então, esse agradecimento especial pelo convite. Fazer uma análise, vamos dizer, da conjuntura política no atual momento é bem difícil, porque não precisa analisar, acho que o que a gente está sentindo, o sentimento que nós estamos passando, é um momento difícil, mas é um momento em que há busca pela nossa unidade, pela união, independente do povo, independente de qual sociedade venha a somar com a gente. Porque na minha visão é que está uma disputa entre o capital e nós, que não dependemos desse capital para viver. Então, essa é a maior luta que temos. Eu acho que as conquistas, nos últimos anos, foram importantes, mas também deixo bem claro que nenhuma delas foi fácil. Todas as conquistas foram através de luta, muita bala de borracha e gás lacrimogênio. Porque eu fiz parte desse grupo de linha de frente e sabemos que não foi fácil, mas o importante é que dentro dessa luta teve um pouco de sensibilidade, a qual a gente não sente nesse atual momento. Para poder chegar também na parte final dessa questão da avaliação nacional, eu penso duas questões que envolvem essa conjuntura política de hoje: uma é o direito originário e outra é a questão do preconceito e do racismo. Em relação ao Brasil, quando a gente tem passado por aí, eu falo que nós, sulistas, somos os únicos que ainda 
vivemos na Europa. Porque os portugueses, os primeiros que chegaram há 518 anos atrás, formaram a população brasileira, mas o sul continua alemão e italiano do mesmo jeito. Ainda não mudou. Por anos e anos, durante essa colonização, durante essas linhas de frente que tiveram na região sul, na colonização, várias vezes foi feita a tentativa de extermínio dos povos indígenas na nossa região. Mas a nossa resistência foi maior e por isso que hoje nós temos a graça de estar lutando aqui, de estar aqui somando forças, através dessa grande luta que foi dos nossos ancestrais e dos nossos antepassados. Essa Europa, quando ela chegou aqui, achou que dominaria a nossa região, e que nos exterminaria, e dominaria o restante do Brasil. Quem aqui não conheceu a história de que o sul se transformaria em um país, se transformaria numa Europa? Existiu essa Europa. O preconceito e o racismo, eu chamo ele de institucional; ele ultrapassou fronteiras. Hoje, quem não foi no Paraguai, por exemplo? Não viu o massacre que os Guarani sofrem no Paraguai? Quem são os que estão lá? São os brasiguaios, que eles chamam. Quem são esses brasiguaios? Gaúchos, catarinas e paranaenses. Esses são os inimigos dos Guarani que estão lá. Quem não vai em São Paulo, por exemplo, quem não vai no Mato Grosso do Sul, quem já foi no Mato Grosso, quem são, de onde que eles saem, de onde que eles surgiram...? Porque aquela guerra lá no passado, quando nós não só retomamos nosso território nos anos 70, mas nós fizemos a autodemarcação, que é diferente de uma retomada. A autodemarcação é: tira o posseiro e bota o indígena lá pra dentro. Quem não lembra? Naquela época, ganhamos a primeira batalha. Mas não ganhamos a guerra. Eles se aperfeiçoaram nessa guerra. Nós temos a Constituição de 88 , éramos soberanos quando a Constituição de 88 foi aprovada e que tivemos dois artigos lá dentro. Nós fomos soberanos ali dentro. Eles se aperfeiçoaram, se aperfeiçoaram juridicamente, politicamente. Hoje, estão nos três poderes. Hoje, esses nossos inimigos, esses nossos antepassados, estão no Executivo, no Legislativo, no Judiciário. E essa herança que eles tiveram da primeira luta em que enfrentaram a resistência sul-brasileira, a resistência indígena do sul, eles levaram com eles ... formaram os filhos deles, os botaram na universidade, os botaram para estudar. Hoje eles ocupam... hoje, nós temos nossos inimigos.Temos muitos procuradores inimigos, temos policiais federais que são nossos inimigos, temos delegados, temos policiais nossos inimigos. Hoje, o preconceito dentro 
das próprias universidades, dentro da própria educação, estão lá dentro nossos inimigos. Nós descobrimos o caminho... o caminho se chama o que nós vemos hoje, muitos jovens que estão aqui, é com muito orgulho que a gente vê a associação dos universitários aqui, indígenas, da UFSC (Universidade Federal da Santa Catarina), estão aqui presentes. Nós aprendemos o caminho, só que nós nunca vamos deixar de ser quem nós somos, indígenas. Nós podemos ser um “formado”, nós podemos ser um mestre, nós podemos ser um doutor, pós-doutor, mas nunca nós vamos deixar de ser indígenas. E nós estamos seguindo esse caminho e estamos abrindo essas universidades, que não é nós nos adaptarmos dentro da universidade, vamos fazer com que essa universidade se adapte a nós. Ela vai ser do nosso jeito, porque a educação não foi construída para respeitar os povos originários do estado brasileiro e ninguém, nenhuma outra sociedade, a não ser a europeia, que é o capital. Mas nós estamos fazendo essa diferença lá dentro. E quando eu falo de território, isso eu quero falar para todos os universitários, o território é nosso. Então, independente de eu estar dentro da universidade, eu estou dentro do meu território, eu não saí de dentro dele. Eu saí da minha terra, onde eu nasci, mas estou dentro do meu território. Então vou dar o meu máximo lá dentro. Se eu estiver morando na cidade, não saí de dentro do meu território, permaneço dentro dele. Então, vou dar o meu máximo lá dentro. É o direito originário... A Constituição brasileira tem entre 233 artigos e 250 artigos. Nós temos dois artigos lá dentro. O povo brasileiro não sabe o que é defender nenhum desses 250 artigos que tem lá dentro. Nós só temos dois, e se nós tivermos que morrer por esses dois artigos, para garantir o futuro dos nossos filhos e das futuras gerações, nós morreremos. Nós somos capazes de dar a nossa vida. Porque a Constituição brasileira não é o principal para garantir o nosso direito, porque quando meus avós me falaram, quando eu me entendi como Kaingang, eu sabia que tenho um direito, chamado direito originário , o qual não prescreve. Nunca vai prescrever. Ele só vai prescrever no dia em que o último índio deixar de lutar. O dia em que ele desistir de lutar, aí o direito originário acaba. Porque eu não vim do barro, eu sou Kaingang, eu não fui feito de barro. As mulheres Kaingang não foram feitas da costela do homem Kaingang. Elas têm uma origem, e essa origem diz que eu vim de um território, e esse território é meu território sagrado, é dali que tiro a minha medicina, é àquele lugar que a minha 
espiritualidade está ligada. Então o direito originário, para cada um de nós que está em luta, - eu estou dentro de uma terra também que foi retomada - só vai deixar de existir a partir da hora que eu esquecer que eu tenho esse direito. Então, não importa se nós estamos passando todas as violências que nós estamos passando, que está sendo esmagador o que o Congresso tem feito com a gente, o Judiciário agora é mais político... o Judiciário hoje, ele é mais político do que o próprio Legislativo. Hoje, quem toma as decisões políticas é o Judiciário e não só o Legislativo. Nós não podemos baixar nossa cabeça em momento nenhum. Temos que continuar firmes, lutando, da maneira que estamos. Para mim, a maior universidade que tem, a maior universidade é a da vida. É a vida nossa, de que nós sabemos e que nós reconhecemos que nós somos passageiros. Mas aquela criança que está sentada ali, não, ela é o futuro, e o futuro dela depende da nossa luta hoje, como foi dos nossos ancestrais e dos nossos antepassados. Nossos pais, nossos avós. Então ela depende de nós, ela depende da luta de hoje. A maior universidade da vida é quem está lutando, quem está buscando uma melhoria paras suas comunidades. Eu tenho o maior orgulho, assim como com certeza o Davi tem, o Marciano tem, quem mora nessa comunidade, de saber que os filhos estão crescendo aqui. Aqui ${ }^{7}$, a gente fica sabendo que estão dando tiros aqui por cima, que buzinam, que ameaçam. [Morro dos cavalos] esses são guerreiros, essas crianças vão crescer com isso na veia, porque nunca vão desistir. E não importa o que vier, não importa. Nós não sabemos quem vai ser o próximo governo, ninguém sabe. Hoje, se a gente for imaginar um novo governo, nós não sabemos, mas a gente tem que colocar uma coisa na cabeça: não importa quem vier, vamos sempre lutar pelo direito originário, que se sobrepõe à Constituição brasileira, ele é acima da Constituição brasileira, ele é acima da convenção 169 da OIT, que é um direito internacional que foi conquistado por nós povos indígenas também. Então esse é o direito pelo qual temos que lutar, e a avaliação política que eu faço, hoje, é que aqueles inimigos cresceram, mas nós seguimos firmes e estamos crescendo bastante, não só em número, em população, mas também no que se refere ao conhecimento acadêmico, mas não desmerecendo nosso conhecimento tradicional, não desconhecendo nosso conhecimento espiritual e não deixando de ser quem nós somos.

\footnotetext{
${ }^{7}$ Cretã refere-se a acontecimentos registrados em entre 2015 e 2017 na TI Morro dos Cavalos.
} 
Podemos ser doutores, mas sempre vamos ser quem somos. A minha fala é essa, e a encerro aqui.

\section{Entrevista}

Entrevistadoras: Gostaríamos que você falasse um pouco sobre sua trajetória, deste lugar de liderança que ocupa hoje.

Cretã: Sou Cretã (Romancil Gentil Cretã), sou do povo Kaingang, região mais central e interior do sul do Brasil. O território Kaingang começa no noroeste de São Paulo, passa pelo norte do Paraná, sudoeste do Paraná, oeste de Santa Catarina, norte do Rio Grande do Sul e envolve uma faixa, quase litorânea, do Rio Grande do Sul, que também é um território Kaingang. Território muito grande, não é? A minha história começou com 30 anos de idade, hoje eu estou com 46. Eu venho de uma família que deu início, aqui na região sul, que foi o Ângelo Cretã, que começou nos anos 70, até nos anos 80, e fizeram as primeiras autodemarcações, o que não é automaticamente uma retomada, é um tipo diferente de luta que consiste em tirar os invasores e recolocar as comunidades indígenas dentro da onde é o seu território, aonde é sua terra originária, dentro do seu território.

Entrevistadoras: Quando você começou este processo de mobilização pela autodemarcação das terras indígenas?

Cretã: Eu comecei um pouco mais tarde, com 30 anos. Eu morei praticamente vinte e poucos anos da minha vida na cidade e não sabia nem o que era movimento indígena, porque eu não tive um aprendizado com o meu pai. Quando ele morreu, eu era muito criança ainda e passei um tempo dentro da comunidade. Com 16 anos, acabei indo pra cidade e tive uma vida na cidade como qualquer outro morador. Sabia que era indígena, mas nunca... não sabia a importância de ser indígena. Meu avô, que se chamava Francisco Luiz dos Santos, lutou durante a Constituição de 88, ele esteve em Brasília, e me visitou em 98 e me chamou pra uma conversa e perguntou quem eu era. "Quem você é?" Daí, falei pra ele, e ele disse "não, você não sabe quem você é, eu vou te contar quem você é". E daí, ele acabou me falando isso, "você é filho do Angelo Cretã, você sabe quem é 
Angelo Cretã?", e foi me contando toda a história do meu pai, a história da minha família, a história da Terra Indígena de Mangueirinha, a história da luta que meu pai fez lá no passado. Daí ele disse "você não é nada, você não é ninguém, você mora aqui na cidade", eu morava numa casinha muito pequena, dividia com o guarda-roupa - pra lá quarto, pra cá cozinha, "e você precisa voltar pra tua aldeia, da onde você veio, precisa fazer um bom trabalho lá dentro e amanhã ou depois se tornar uma liderança dentro da comunidade, pra a partir daí, você ajudar aquela comunidade que precisa de você, dar continuidade ao trabalho do seu pai pra você se tornar uma liderança regional e depois se tornar uma liderança nacional”. Perdi ele um mês depois. Meu avô acabou morrendo e eu ainda permaneci em Curitiba porque eu não conseguia entender o que era a visão dele. Eu sabia que tinha alguma coisa dentro de mim, mas não sabia o que era e não sabia o caminho a seguir. Mas demorou alguns anos ainda.

Entrevistadoras: Como foi esta experiência de se perceber como parte de uma nação indígena?

Cretã: A minha primeira experiência foi em 1993, quando nós começamos a nos encontrar com uns índios urbanos em Curitiba, criamos a associação de índios urbanos que moravam em Curitiba, tivemos algumas conquistas, inclusive uma terra que tem hoje no município, uma terra indígena chamada Kakané Porã, que é... kakané, em Kaingang, é fruto e porã é bom, "frutos bons" o nome da comunidade, então foi uma das conquistas da associação e daquela organização que a gente criou. Depois, pra chegar a ser coordenador, por exemplo, na Arpin Sul, que é a nossa organização regional, foi rápido esse processo, e pra poder chegar no nível de hoje e fazer parte desse movimento nacional. Meu pensamento sobre a questão da importância da terra é o seguinte: para nós, mais especificamente pra questão Kaingang, é que o entendimento meu, assim, não é através do direito, que é esse direito constitucional e nem o direito hoje, por exemplo, a convenção 169 da Organização Internacional do Trabalho (OIT), que nos dá esse direito. Pra mim, o maior direito é o direito originário que emos, porque eu não sou Kaingang por acaso. Por exemplo, eu não vim do barro, não está escrito em Bíblia que eu vim do barro, não está escrito que as nossas mulheres Kaingang vieram da nossa costela. Nós temos uma origem e essa origem é que garante o território, a nossa terra e o nosso direito de 
dar nossa própria vida por aquela terra, por aquele território. Eu ainda consigo ter na minha terra, onde eu nasci, que é a terra indígena Mangueirinha, que ainda é a maior reserva de araucária do mundo ainda. É uma reserva muito bem preservada, $80 \%$ dela ainda é floresta de araucária, mas as outras terras indígenas Kaingang, por exemplo, em todo o sul do Brasil, já não têm mais araucária, não existe mais, é só na terra indígena Mangueirinha. Hoje eu estou vivendo numa terra chamada, numa terra indígena que há quatro anos nós ocupamos, que se chama Tupã Nhe'é Cretã, que foi um Xamã que deu esse nome, homenageou a família Cretã. A gente tem um sobrenome de família e esse sobrenome é o nome que nós usamos pra poder fazer os nossos trabalhos e, com certeza, meus filhos também vão carregar esse nome e têm esse compromisso de continuar lutando, porque o avô deles teve esse nome, o bisavô deles teve esse nome Cretã, eu hoje carrego esse nome Cretã. Então é uma grande responsabilidade, não só como família, mas como Kaingang.

Entrevistadoras: Você poderia nos falar um pouco sobre a mobilização nacional indígena, no Brasil?

Cretã: Tudo que a gente faz no Movimento nacional, hoje, é pensando no melhor de todos os povos. Nós não pensamos especificamente na questão Kaingang, mas pensamos no pensamento dos povos indígenas daqui da região sul, os povos indígenas do Brasil. Hoje eu sou casado, a minha mulher é Guarani, meus filhos são Kaingang e são Guarani também, e sentimos que temos ainda que fortalecê-losmuito mais. Eu sou muito orgulhoso de viver numa terra que é retomada, que os meus filhos estão se criando lá dentro, com todas as dificuldades que a gente teve no começo, e que, agora, já não são tantas. Acho que a importância das crianças se criarem dentro de uma área de retomada, de uma terra dentro de um território, é isso que garante às futuras gerações continuarem na luta. Eu sempre falo que eu não tinha chance nenhuma para quase nada na minha, por ter ido para a cidade muito jovem, por ter vivido na cidade. Eu, por exemplo, sou pedreiro, sou carpinteiro, sou metalúrgico, sou vigilante... trabalhei em vários empregos, eu podia estar lá, na cidade, mas a força dos nossos ancestrais, a força dos nossos pais, a força dos nossos avós, a força espiritual que envolve os povos indígenas, estas forças.... 
elas te buscam. Eu sempre falo para os jovens, pra quem tá entrando no movimento, seja indígena, não indígena, que não é você que entra para o movimento, não é você que o espírito chama, não é você que quer ir para o espírito; na verdade, o espírito te chama. 0 movimento te chama, o movimento te reconhece, o espírito te reconhece como uma parte dessa força. Então eu podia hoje ser o que eu quisesse lá fora, mas não. Eu, hoje, sou muito feliz por hoje estar morando dentro das terras indígenas, sou muito feliz de ser originário da terra indígena Mangueirinha.

\section{Entrevistadoras: Poderia nos contar um pouco mais sobre a herança de seu pai?}

Cretã: Hoje eu entendo Ângelo Cretã como um líder muito forte na época e muito forte nos dias de hoje, porque ele sempre está no nosso meio. Dificilmente o chamo de pai, eu o chamo mais de Ângelo, pra reconhecer o líder que ele era, porque eu podia simplesmente falar "meu pai”, mas não, eu chamo de líder. E esse nome que ele deixou eu procuro fazer jus, para ajudar as pessoas, porque talvez eu não fosse nada se não tivesse o nome e também se não fosse o chamado, eu não seria ninguém. A princípio eu acredito que seja isso...

Entrevistadoras: Quando você foi para a cidade manteve a língua ou também perdeu o contato com o Kaingang?

Cretã: Não, porque eu já saí com 16 anos, então com isso não tive dificuldade, mas eu vivia igual ao não índio lá fora. Trabalhei em empresas e tudo, inclusive fui numa época em que, hoje, o preconceito e o racismo são muito fortes, mas na época também eram. Eu tive vários apelidos. Eu tinha apelido de japa, de chinês, de japonês nas empresas onde eu trabalhava. Mas eu nunca falava que era índio, porque tinha muito bullying que chamam, né, muita piadinha com os indígenas, então eu procurava não falar. Eu trabalhava, mostrava que tinha capacidade para estar ali, trabalhava muito bem, nunca fui só um simples funcionário dentro das empresas. Eu sou ex-militar também, não fui só um soldadinho lá dentro, fui um bom soldado, fui atleta no exército, fui das Operações Especiais do Exército. Então, nunca fui uma simples pessoa, desde que eu saí da minha comunidade, eu sempre procurei, nos locais onde estive, sempre mostrar pra quem tirava 
sarro de indígena, para quem fazia bullying com indígena, era mostrar que nós temos capacidades iguais a todos. Temos condições de trabalhar de igual para igual, então essa era uma das coisas que eu fazia sempre.

Entrevistadoras: Você falou sobre a diferença entre autodemarcação e área retomada, pode falar um pouco melhor sobre estas diferenças?

Cretã: Então, a retomada é quando você chega num local e ocupa ele; ali você ocupou e você vai fazer o processo da demarcação daquela área, a desintrusão ${ }^{8}$, através da justiça, através da indenização que é feita para aquela comunidade, feita para aqueles que estavam ali, através do laudo antropológico, através do reconhecimento como uma terra indígena do local. A autorretomada é o contrário, a autorretomada é quando você chega naquele local onde era uma terra indígena e todos os invasores daquela terra indígena são retirados e são recolocadas as famílias nas casas, nos locais onde eles moram. Essa é a autodemarcação, que foi o que o Ângelo Cretã fez e junto com os Guarani, os Kaingang e os Guarani, na época, fizeram essa luta e fizeram a autodemarcação. Hoje, a autodemarcação acontece muito no povo Terena. Os Terena tiram os fazendeiros e colocam as famílias para morar nessas fazendas. Eu moro hoje numa área de retomada. Retomei essa terra dentro do território Kaingang, o último planalto do Paraná, antes da descida da Serra do Mar, é onde era uma região de Kaingang, que é a divisa de São José dos Pinhais com Morretes ${ }^{9}$, bem naquela divisa.

\section{Entrevistadoras: Como chamam esta área?}

Cretã: Tupã Nhe' é Cretã, nome que o xamã deu... porque Cretã em Kaingang é "espírito da montanha” e Tupã Nhéé é “deus da montanha”, daí ele juntou os dois e disse que o lugar se chamaria “deuses da montanha”, Terra Indígena Deuses da Montanha, porque juntou o espírito com Deus, aí, ficou “deuses da montanha”.

\footnotetext{
8 Medida legal relacionada ao processo demarcatório das terras indígenas, relacionada a retirada de eventuais ocupantes não-indígenas dos territórios declarados tradicionais, em geral incluindo indenizações.

${ }^{9}$ Cretã se refere a dois municípios do litoral paranaense, próximos a Curitiba.
} 
Trajetórias de vidas e lutas pela demarcação das terras indígenas. Uma entrevista com Cretã Kaingang

Universidade do Estado de Santa Catarina - UDESC

Centro de Ciências Humanas e da Educação - FAED

Revista PerCursos

Volume 19 - Número 39 - Ano 2018 revistapercursos@gmail.com 